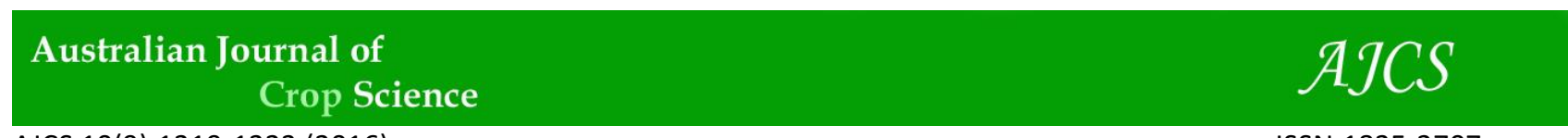

AJCS 10(9):1319-1323 (2016)

ISSN:1835-2707

DOI: $10.21475 /$ ajcs.2016.10.09.p7814

\title{
Fruit biometry, germination and seed vigor of Mimosa setosissima Taub.: Conservation of a rare Cerrado species
}

\author{
Daniel Cardoso Brandão ${ }^{1}$, Lucas Marquezan Nascimento ${ }^{1}$, Carlos de Melo e Silva-Neto ${ }^{1}$, Anna Carla \\ Souza Luccas ${ }^{1}$, Aniela Pilar Campos de Melo ${ }^{2 *}$, Leandra Semensato ${ }^{1}$, Larissa Leandro Pires ${ }^{1}$, \\ Alexsander Seleguini ${ }^{1}$
}

\author{
${ }^{1}$ Sector of Horticulture, Federal University of Goiás, Campus Samambaia, Zip Code: 74900-000; Goiânia, GO, \\ Brazil \\ ${ }^{2}$ Group Conhecer, Scientific Center Conhecer, Zip Code: 74.280-110; Goiânia, GO, Brazil
}

*Corresponding author: niela.pcdmelo@gmail.com

\begin{abstract}
Mimosa setosissima is a tree species, considered rare once its occurrence is restricted to the Cerrado biome. Studies on this species may contribute to its conservation. Thus, the objective of this study was to characterize the fruits (physically) and seeds (physiologically) of M. setosissima to provide supporting information for the commercial and conservational propagation of the species. The pods ( $\mathrm{n}=200$ fruits) of M. setosissima were collected from plants present in the Cerrado Rupestre of the Serra dos Pirineus State Park, Goiás, Brazil. The fruit were separated into two maturation classes regarding to the color and texture of the pods (brown and green). The pods of each maturity stage were characterized by the following attributes: fresh weight, length, width, thickness, number of seeds, number of normal and abnormal seeds (dead/rotten/damaged/broken). A germination test was used to evaluate the physiological potential of seeds. The germination test applied in a factorial $(2 \times 2)$ randomized design, with two fruit ripening stages (brown and green) and two substrates (between paper and paper roll and on paper in a gerbox) (temperature $25^{\circ} \mathrm{C}$; $12-$ hour photoperiod; humidity $75 \%$ ). The morphobiometrics of $M$. setosissima fruit depends on the maturity stage, where an increased growth was observed in brown fruits. The substrate "between paper and paper roll" is more appropriate to conduct the germination test of seeds $M$. setosissima. Seeds coming from green pods have a physiological performance higher than that of brown seed pods.
\end{abstract}

Keywords: rare species, Fabaceae, physiological seed potential.

Abbreviation: BOD_Biological Oxygen Demand; G4_first count of seeds; DWS_dry weight of seedling; FWS_fresh weight of seedling; G20_final germination; GSI_germination speed index; M_Maturation; SH_shoot height; S_Substrate; RL_root length.

\section{Introduction}

The diversity found in natural Cerrado vegetation may become sources for the livelihoods of rural families, mainly through the extraction and development of new products (industrial, food and medicinal) (Pereira et al., 2012). In addition, the called modern landscaping has been adopted, advocating the use of native species instead of exotic species (Heiden et al., 2006; Leal and Biondi, 2006). The increase of green areas and the maintenance of local biodiversity favors the use of native species in urban landscaping (De Araújo and Pires, 2009). In addition, the rusticity and adaptability of this species to the environment is highlighted (Lima, 1990), culminating in lower cost of implementation and maintenance. The specie Mimosa setosissima Taub., found only at altitudes above $1200 \mathrm{~m}$, is highlighted among rare species and species with high ornamental and landscape potential in the Cerrado biome (Simon and Hay, 2003; Giulietti et al., 2009). Although a rare species, the morphological and physiological characteristics of conciliating plant with its scenic beauty makes it suitable for use in landscaping and ornamentation (Nichols, 2005).

Information concerning fruit biometry, germination and seed vigor of $M$. setosissima are scarce. The morphobiometry of such structures is important to support the taxonomic and phylogenetic characterization of the species, the formulation of protocols for propagation and the evaluation of the physiological/physical/pathological quality of seeds (De Macedo et al., 2009; Moura et al., 2010; Pereira et al., 2011). For use in landscaping and ornamental kind of rare plant and therefore protected by Brazilian law (Brazil, 1998), the propagation of the species should happen in a way that does not cause damage to the specimens and maximize the use of seeds, thus preventing the reduction of the natural population (Nichols, 2005). Together the propagation of rare species can also be considered conservation strategies, since increasing the number of specimens that can later be reintroduced into the natural environment (Arianoutsou et al., 2012). Given the above, the objective of this study was to characterize the fruits (physically) and seeds (physiologically) of $M$. setosissima to provide supporting information for the commercial and conservational propagation of the species. 


\section{Results and discussion}

\section{Fruit and seed biometry}

The pod maturity stage affected fresh weight accumulation of the pod $(\mathrm{p} \leq 0.001)$ and seeds $(\mathrm{p} \leq 0.001)$, thickness $(\mathrm{p}=0.042)$, number of seeds $(\mathrm{p} \leq 0.001)$, number of normal seeds $(p \leq 0.001)$ and number of abnormal seeds $(p \leq 0.001)$. The descriptive values of the morphobiometric variables of fruits and seeds of $M$. setosissima are shown in Table 1. Pods from brown fruits had a higher fresh weight associated with a greater thickness (Table 1). The combination of the epicarp color along with the higher fresh weight may indicate that this fruit has reached physiological maturity.

The number of abnormal seeds was higher in green pods (Table 1). The higher humidity content and lower development level may increase the detection of immature seeds and the incidence of pathogens causing decay. The biometric characteristics of green pods varied more than brown pods (Table 1). Green pods had a high variability in regards to thickness and number of normal and abnormal seeds, probably due to the lack of dehiscence associated with immaturity in fruit growth. M. setosissima fruits exhibited low length and width variation, regardless of the maturity stage. Similarly, Schulz et al. (2014) reported no considerable variation in length and diameter of Inga laurina (Sw.) Wild. fruit in different maturity stages. The proximity between matrices (maximum radius of occurrence of 50 meters) may be another associated factor, culminating in low genetic variability (Valadares et al., 2009). M. setosissima is a rare species with very restricted geographic distribution. In addition, spatially closer plants exhibit a higher genetic similarity than the expected by chance (Soares et al. 2008).

The first and second components of the multivariate analysis for the morphobiometric traits of pods explained over $99 \%$ of the variance observed in the data (Fig. 1). The pod types are located in different quadrants, indicating the great dissimilarity between dry and green pods in regards to morphobiometric traits. The main morphological descriptors of green pods are width and length. However, dry pods were not associated with any morphobiometric trait.

\section{Seed germination and vigor}

The interaction between factors (fruit maturation $\mathrm{x}$ substrates) occurred during the first count (germination four days after sowing), final germination (germination 20 days after sowing), and for the germination speed index and root length (Table 2). The germination performance and vigor of seedlings from seeds found in green pods was superior to brown pods (Table 2, Fig. 2), especially for the substrate "between paper and paper roll" (Table 3). Thus, the physiological maturity of seeds may be inferred to occur prior to the complete ripening of fruits. Brown pods had an apparently higher number of seeds (Table 1), although it did not result in a better performance. The seeds from brown pods possibly have an early disengagement from the parent plant, leading to an advanced metabolic deterioration and consequent worse physiological performance (Marcos-Filho, 2009). The lack of synchrony in the maturation of fruits and seeds occurs in many species, forest as well as horticultural, such as Tabebuia chrysotricha (Mart. Ex DC.) Standl (Yellow Ipe) (Fonseca et al., 2005), Tabebuia impetiginosa (Mart. Standl.) (Purple Ipe) (Germaque et al., 2002) and Capsicum annum L. (jalapeño pepper) (Ricci et al., 2013). It is noteworthy that the collection of fruit for seed extraction may be optimized by visual indicators of fruit maturation (Hirano and Possamai, 2008), providing better decision making to collectors and nursery gardeners to encourage seedling production.

The final germination of seeds from green pods was $86.50 \%$, nearly three times larger than the reported previously for $M$. setosissima seeds collected at Pirenopólis, Serra dos Pirineus (25\%; Simon and Hay 2003). However, Simon and Hay (2003) did not describe the stage of fruit ripening in which the seeds were removed, mentioning only that the fruit were collected without dehiscence and that were subsequently dried in the laboratory. The substrate "between paper and paper roll" provided a better physiological performance, considering germination and vigor for $M$. setosissima seeds (Table 2 and Table 3). Similar results were also reported by Alves et al. (2002) for M. caesalpiniaefolia Benth seeds. The substrate "on paper of the gerbox" possibly led to a lower seed contact to the surface, undermining the soaking and subsequent germination (Guedes and Alves, 2011). M. setosissima seedling from green pods found in the substrate "between paper and paper roll" had a satisfactory growth (Table 2). There were no differences in the accumulation of water (fresh weight) and dry matter in the tissues, although these seedlings had greater shoot height associated to a lower expansion of the root system. This can be observed through the lower root length/shoot height ratio for green pods (0.51) and "between paper and paper roll" (0.47), compared to brown pods (0.75) and "on paper" (0.87). Therefore, there was an optimized allocation of seed reserves for seedling formation and not to capture moisture in the substrate.

\section{Materials and Methods}

\section{Plant materials}

Mimosa setosissima is a Fabaceae with distribution restricted to the states of Goiás and the Distrito Federal, located in the Midwestern region of Brazil. The species has no specific name in English, but commonly, this genus is generically named Mimosa. It is a shrub that may reach three meters in height, with rounded crown and whitish stem. The leaves are pilose, composed and multifoliated. Flowering occurs from May to September. The flowers are pinkish-purple and small, in a glomerular arrangement, popularly called "pompom".

\section{Fruit collection}

The M. setosissima pods were collected from plants present in Cerrado Rupestre in the Serra dos Pirineus State Park

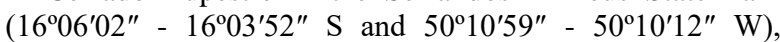
Goiás, Brazil. According to Koppen, the climate in the region is Aw, characterized by a rainy summer and dry winter (Digital map of access to M. setosissima population)

\section{Biometric characterization of fruits and seeds}

A random design with two treatments and ten iterations was adopted for the biometric characterization of fruits and seeds. The fruits were characterized in regards to maturity stage, based on the color and texture of the pod, into two assessment classes: brown (dry) and green. Each plot comprised ten pods. The variables fresh weight $(\mathrm{g})$, length $(\mathrm{mm})$, width $(\mathrm{mm})$, thickness $(\mathrm{mm})$, number of seeds per pod number of normal seed per pod and number of abnormal seeds (dead/rotten/damaged/broken/immature) per pod were 
Table 1. Descriptive parameters of morphobiometric variables of pods and seeds of $M$. setosissima according to the fruit maturity

\begin{tabular}{|c|c|c|c|c|}
\hline Variable & Minimum & Maximum & Mean & $\mathrm{CV}$ \\
\hline & & \multicolumn{3}{|l|}{ Dry pod } \\
\hline Fresh weight (g) & 0.80 & 1.13 & 1.00 & 9.2 \\
\hline Length $(\mathrm{mm})$ & 26.97 & 41.55 & 33.92 & 15.56 \\
\hline Width (mm) & 8.76 & 12.87 & 10.91 & 11.95 \\
\hline Thickness (mm) & 5.52 & 8.85 & 6.96 & 14.85 \\
\hline Total seeds & 6.3 & 7.5 & 7.06 & 5.12 \\
\hline Normal seeds & 6.0 & 7.5 & 6.73 & 5.86 \\
\hline Abnormal seeds & 0.00 & 0.08 & 0.33 & 75.65 \\
\hline \multirow{2}{*}{ Fresh weight of seeds (g) } & 0.05 & 0.08 & 0.069 & 13.97 \\
\hline & & \multicolumn{3}{|l|}{ Green pod } \\
\hline Fresh weight (g) & 0.35 & 0.54 & 0.457 & 12.08 \\
\hline Length $(\mathrm{mm})$ & 30.19 & 38.27 & 34.33 & 8.48 \\
\hline Width (mm) & 8.84 & 12.47 & 10.78 & 11.97 \\
\hline Thickness (mm) & 2.92 & 6.85 & 5.82 & 22.02 \\
\hline Total seeds & 4.3 & 6.9 & 5.65 & 14.28 \\
\hline Normal seeds & 3.1 & 5.9 & 4.10 & 21.26 \\
\hline Abnormal seeds & 1.0 & 2.5 & 1.55 & 28.40 \\
\hline Fresh weight of seeds (g) & 0.03 & 0.05 & 0.04 & 17.80 \\
\hline
\end{tabular}

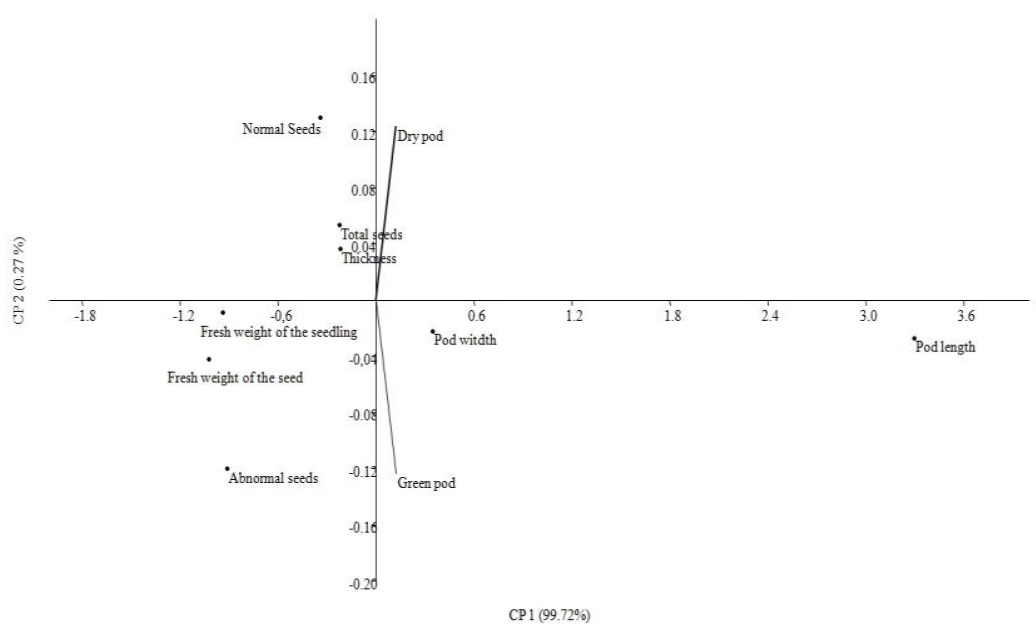

Fig 1. Biplot of morphobiometric traits of dry and green pods of M. setosissima in regards to components 1 and 2.

determined $(n=100$ fruits for each class and the number of seeds is variable between fruit). The data were assessed through descriptive statistics (measures of central tendency and dispersion) and multivariate analysis using a Principal Components Analysis. The significance of the effect of the treatments was determined using the $\mathrm{F}$ test.

\section{Seed germination and vigor, and seedling growth}

The seeds extracted from brown and green fruits were weighed to determine the fresh weight. Then, the seeds were placed in plastic containers and stored in a cooling chamber $\left(5{ }^{\circ} \mathrm{C}\right)$. A randomized design in a $2 \times 2$ factorial was adopted, comprising two fruit ripening stages (brown-dry, green) and two germination substrates (between paper and paper roll and on paper in a gerbox), eight repetitions and 25 seeds per plot. The substrates were moistened with distilled water until reaching three times its dry mass. The boxes and paper rolls were kept in a $\mathrm{BOD}$ incubator (temperature $25^{\circ} \mathrm{C} ; 12$-hour photoperiod). Seed germination was assessed four (first count), six, eight, eleven, fourteen and twenty (final germination) days after sowing, to calculate the germination speed index (Maguire, 1962). A seed was considered having germinated when emitted a radicle with at least two millimeters. The results were expressed in percentage. Growth analysis of the seedlings was conducted 27 days after sowing. The following variables were determined: fresh weight $(\mathrm{g})$, dry matter $(\mathrm{g})$, shoot height $(\mathrm{cm})$ and root length (cm). A total of four seedlings were collected in each repetition, and were weighed in an analytical balance (precision of $0.001 \mathrm{~g}$ ), to measure the fresh weight. Shoot height and root length were measured using a graduated scale in millimeters. Then, the seedlings were placed in paper bags and dried in the oven $\left(60^{\circ} \mathrm{C}, 72 \mathrm{~h}\right)$ to determine dry matter. The $\mathrm{F}$ test determined the significance of the effects of the treatments. The Tukey test was employed to assess the interactions between the factors "fruit ripening stage" and "substrates". 
Table 2. Germination and vigor of M. setosissima seeds from pods in two maturity stages, cultivated in two substrates in the germination test: first count (G4), final germination (G20), germination speed index (GSI), fresh weight of seedling (FWS), dry weight of seedling (DWS), shoot height (SH), root length (RL).

\begin{tabular}{llllllll}
\hline Treatments & $\mathrm{G} 4$ & $\mathrm{G} 20$ & $\mathrm{GSI}$ & $\mathrm{FWS}$ & $\mathrm{DWS}$ & $\mathrm{SH}$ & $\mathrm{RL}$ \\
\cline { 2 - 9 } Maturation (M) & $\%$ & $\%$ & & $\mathrm{~g}$ & $\mathrm{~g}$ & $\mathrm{~cm}$ & $\mathrm{~cm}$ \\
Dry-Brown & 4.00 & 19.00 & 2.07 & 0.11 & 0.016 & 2.97 & 2.25 \\
Green & 1.00 & 86.50 & 6.04 & 0.12 & 0.014 & 3.35 & 1.74 \\
$\mathrm{~F}$ & $12.00^{* *}$ & $720.76^{* *}$ & $165.98^{* *}$ & $1.53 \mathrm{~ns}$ & $1.70 \mathrm{~ns}$ & $3.28 \mathrm{~ns}$ & $5.35^{*}$ \\
\hline Substrate (S) & & & & & & & \\
On the paper & 0.5 & 51.50 & 4.23 & 0.10 & 0.016 & 2.57 & 2.24 \\
Between paper and paper & 4.5 & 54.00 & 3.85 & 0.13 & 0.014 & 3.75 & 1.75 \\
roll & & & & & & \\
$\mathrm{F}$ & $21.33^{* *}$ & $0.98 \mathrm{~ns}$ & $1.26 \mathrm{~ns}$ & $9.12^{* *}$ & $1.40 \mathrm{~ns}$ & $31.04^{* *}$ & $4.95^{*}$ \\
\hline $\mathrm{F}(\mathrm{M} \mathrm{x} \mathrm{S})$ & $12.00^{* *}$ & $14.27^{* *}$ & $0.48 \mathrm{~ns}$ & $5.17^{*}$ & $0.16 \mathrm{~ns}$ & $9.59^{* *}$ & $0.63 \mathrm{~ns}$ \\
\hline
\end{tabular}

ns - non significant; * significant $(\mathrm{p} \leq 0.05) ; * *$ significant $(\mathrm{p} \leq 0.01)$

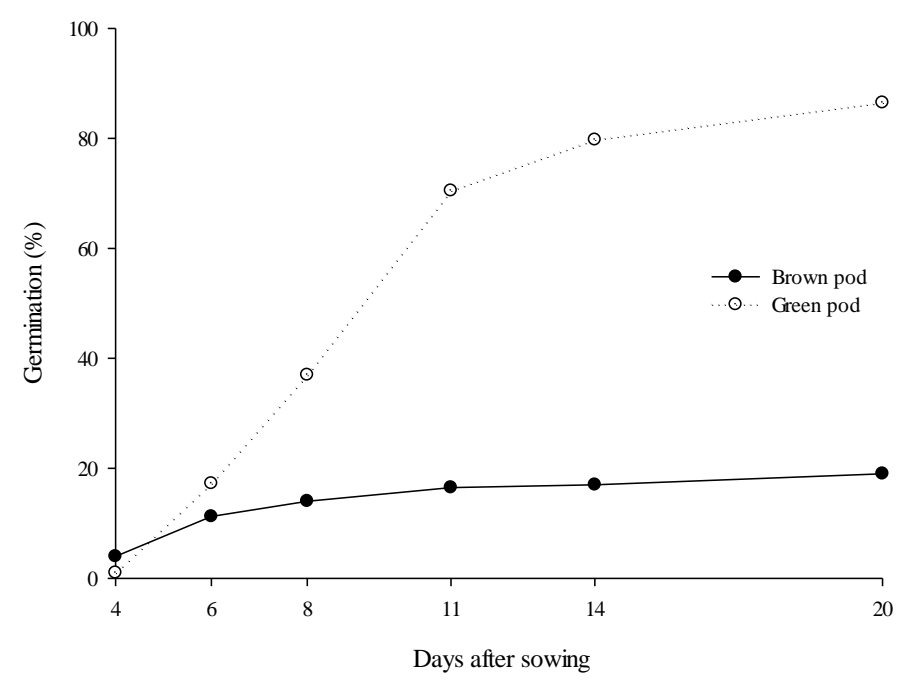

Fig 2. Evolution of the germination of M. setosissima seeds from pods in different maturity stages.

Table 3. Breakdown of the interactions between the factors "Maturity stage" and "substrates" for the variables first count (G4), final germination (G20), fresh weight of seedlings (FWS) and shoot height (SH).

\begin{tabular}{|c|c|c|c|c|}
\hline & \multicolumn{3}{|c|}{ G4 } & 20 \\
\hline \multirow{3}{*}{$\begin{array}{l}\text { Dry-Brown } \\
\text { Green }\end{array}$} & On paper & $\begin{array}{l}\text { Between paper and } \\
\text { paper roll }\end{array}$ & On paper & $\begin{array}{l}\text { Between paper and } \\
\text { paper roll }\end{array}$ \\
\hline & $0.5 \mathrm{aB}$ & $7.5 \mathrm{aA}$ & $22.50 \mathrm{bA}$ & $15.50 \mathrm{bA}$ \\
\hline & $0.5 \mathrm{aA}$ & $1.5 \mathrm{bA}$ & $80.50 \mathrm{aB}$ & $92.50 \mathrm{aA}$ \\
\hline & FWS & & $\mathrm{SH}$ & \\
\hline & On paper & $\begin{array}{l}\text { Between paper and } \\
\text { paper roll }\end{array}$ & On paper & $\begin{array}{l}\text { Between paper and } \\
\text { paper roll }\end{array}$ \\
\hline Dry-Brown & $0.11 \mathrm{aA}$ & $0.11 \mathrm{bA}$ & $2.70 \mathrm{aA}$ & $3.23 \mathrm{bA}$ \\
\hline Green & $0.10 \mathrm{aB}$ & $0.15 \mathrm{aA}$ & $2.43 \mathrm{aB}$ & $4.28 \mathrm{aA}$ \\
\hline
\end{tabular}

Means followed by the same lower case letter in the column and upper case letter in the line do not differ by the Tukey test ( $\mathrm{p} \leq 0.05)$

\section{Conclusions}

The morphofruit biometrics of $M$. setosissima depends on the maturity stage. The substrate "between paper and paper roll" is the most appropriate for the germination test of $M$. setosissima seeds. Seeds derived from green pods exhibit greater vigor than seed from brown pods. Thus, for greater utilization of $M$. setosissima seeds it is recommended to use seeds from green pods to germination.

\section{Acknowledgements}

The research group is grateful to the Postgraduate Program in Agronomy of the Federal University of Goiás (UFG), the National Council for Scientific and Technological Development (CNPq) and Higher Education Personnel Improvement Coordination (CAPES) for master's and doctoral scholarships and all the support. 


\section{References}

Alves EU, Paula RC, Oliveira AP, Bruno RLA, Diniz AA (2002). Germinação de sementes de Mimosa caesalpiniaefolia Benth. em diferentes substratos e temperaturas. Rev Bras Sem. 24: 169-178.

Arianoutsou M, Leone V, Moya D, Lovreglio R, Delipetrou P, de lãs Heras J. (2012). Management of threatened, high conservation value, forest hotspots under changing fire regimes. In: Moreira F, Arianoutsou M, Corona P, de las Heras J. (Eds). Post-Fire Management and Restoration of Southern European Forests. Springer Netherlands.

Brazil (1998). Lei $N^{\circ}$ 9.605, de 12 de Fevereiro de 1998. Leis de Crimes Ambientais. Access in: http://www.planalto.gov.br/ccivil_03/leis/L9605.htm

De Araújo RCR; Pires LL (2009). Opções de frutíferas do Cerrado para paisagismo urbano em bairros da periferia de Goiânia-GO. Rev Caatinga. 22: 235-239.

De Macedo MC, Sacalon SPQ, Sari AP, Sacalon-Filho H, Rosa YBCJ, Robaina AD (2009). Biometria de frutos e sementes e germinação de Magonia pubescens ST. Hil (Sapindaceae). Rev Bras Sem. 31: 202-211.

Fonseca FL, Menegario C, Mori ES, Nakagawa J (2005). Maturidade fisiológica das sementes do ipê amarelo, Tabebuia chrysotricha (Mart. Ex DC.) Standl. Sci For. 12:1 36-141.

Germaque RCR, Davide AC, Faria JMC (2002). Indicadores de maturidade fisiológica de sementes de ipê-roxo (Tabebuia impetiginosa (Mart.) Standl.). Cerne 8: 84-91.

Giulietti AM, Rapini A, Andrade MJG, Queiroz LP, Silva JMC (2009). Plantas raras do Brasil. Belo Horizonte, Conservação Internacional.

Guedes RS, Alves EU (2011). Substratos e temperaturas para testes de germinação de sementes de Chorisia glaziovii (O) Kuntze). Cerne. 17: 525-531.

Heiden G, Barbieri RL, Stumpf ERT (2006). Considerações sobre o uso de plantas ornamentais nativas. Rev Bras Hort Orn. 12: 2-7.

Hirano E, Possamai E (2008). Estádio de maturação do fruto e germinação de sementes de três espécies de Lauraceae. Sci Agra. 9: 219-223.

Leal L, Biondi D (2006). Potencial ornamental de espécies nativas. Rev Cien Elet Eng Flor. 4: 1-16.

Lima VF (1990). Utilização de espécies do cerrado em paisagismo. Acta Bot Bras. 4(20): 87-93.
Maguire JD (1962). Speed of germination-aid in selection and evaluation for seedlig emergence and vigor. Crop Sci. 2: $176-177$.

Marcos-Filho J (2005). Fisiologia de sementes de plantas cultivadas. Piracicaba: FEALQ. 495 p.

Moura RC, Lopes PSN, Brandão-Junior DS, Gomes JG, Pereira MB (2010). Fruit and seed biometry of Butia capitata (Mart.) Beccari (Arecaceae), in the natural vegetation of the North of Minas Gerais, Brazil. Biota Neot. 10: 415-419.

Nichols G (2005). Growing rare plants: a practical handbook on propagating the threatened plants of southern Africa. Southern African Botanical Diversity Network Report n. 36. Sabonet, Pretoria.

Pereira SR, Giraldelli GR, Laura VA, Souza ALT (2011). Fruit and seed size and their influence on the germination of Hymenaea stigonocarpa var. stigonocarpa Mart. ex Hayne (Leguminosae - Caesalpinoideae). Rev Bras Sem. 33:141-148.

Pereira ZV, Fernandes SSL, Sangalli A, Mussury RM (2012). Usos múltiplos de espécies nativas do bioma Cerrado no Assentamento Lagoa Grande, Dourados, Mato Grosso do Sul. Rev Bras Agroecol. 7: 126-136.

Ricci N, Pacheco AC, Conde AS, Custódio CC (2013). Qualidade de sementes de pimenta jalapenho em função da maturação e tempo de permanência nos frutos. Pesq Agrop Bras. 43: 123-129.

Schulz DG, Oro P, Volkweis C, Malavasi MM, Malavasi UC (2014). Maturidade fisiológica e morfometria de sementes de Inga laurina (Sw.) Willd. Flor Amb. 21: 45-50.

Simon MF, Hay JD (2003). Comparison of a common and rare species of Mimosa (Mimosaceae) in Central Brazil. Aust Ecol. 28: 315-326.

Soares TN, Chaves LJ, Telles MPC, Diniz JAF, Resende LV (2008). Distribuição espacial da variabilidade genética intrapopulacional de Dipteryx alata. Pesq Agrop Bras. 43:1151-1158.

Valadares J, Paula RC, Môro FV (2009). Germinação, desenvolvimento de plântulas e teste de tetrazólio em Poecilanthe parviflora Bentham (Fabaceae - Faboideae). Científica. 37: 39-47. 